\title{
Understanding brand and dealer retention in the new car market: The moderating role of brand tier
}

\author{
Peter C. Verhoef ${ }^{\mathrm{a}, *}$, Fred Langerak ${ }^{\mathrm{b}}$, Bas Donkers ${ }^{\mathrm{c}}$ \\ ${ }^{a}$ University of Groningen, School of Economics, Department of Marketing, P.O. Box 800, NL-9700 AV Groningen, The Netherlands \\ ${ }^{\mathrm{b}}$ Rotterdam School of Management, Erasmus University, Department of Marketing Management, \\ Office T10-16, P.O. Box 1738, NL-3000 DR Rotterdam, The Netherlands \\ ${ }^{\mathrm{c}}$ Rotterdam School of Economics, Erasmus University, Office H15-19, P.O. Box 1738, NL-3000 DR Rotterdam, The Netherlands
}

\begin{abstract}
Dealers may contribute to brand retention through their sales and service efforts. In this study we investigate the degree to which dealers contribute to brand retention and how this contribution is moderated by brand tier. To this end we distinguish between economy, volume and prestige brands. We also investigate how the effectiveness of dealer instruments to increase dealer retention differs across these brand tiers. We collected data on brand retention and dealer retention among consumers who recently purchased a new car. Our findings show that dealers selling volume brands are able to improve brand retention rates. In contrast, dealers of prestige and economy brands are unable to affect brand retention. In line with the notion of brand-dealer fit we also find that the effects of dealer extrinsic service quality and dealer payment equity on dealer retention differ between prestige, volume, and economy brands. Extrinsic dealer service quality has the smallest effect for dealers selling economy brands, while dealer payment equity is the most important determinant of dealer retention for these dealers.
\end{abstract}

(C) 2006 New York University. Published by Elsevier Inc. All rights reserved.

Keywords: Brand loyalty; Dealer loyalty; Brand-dealer fit; Brand tiers

\section{Introduction}

In many markets manufacturers sell products using dealers as intermediaries. Both the brand manufacturer and the dealer strive to enhance their respective retention rates. Dealer and brand retention decisions are often interrelated because consumers' brand retention decisions may be dependent upon the dealers' performance. This especially holds in markets where dealers are expected to add substantial value to the brand they sell, such as the new car market. Most manufacturers therefore strive after close ties with their dealers to assure high levels of service quality to increase brand retention rates (Anderson and Narus 1995; Chu and Desai 1995).

The interplay between brand retention and dealer loyalty has received little attention in the literature. Past research has mostly examined how dyadic relationships (i.e., consumer-manufacturer or consumer-dealer) impact con-

\footnotetext{
* Corresponding author.

E-mail addresses: p.c.verhoef@rug.nl (P.C. Verhoef), f.langerak@rsm.nl (F. Langerak), donkers@ @ew.eur.nl (B. Donkers).
}

sumers' intentional loyalty (e.g., Anderson and Sullivan 1993; Garbarino and Johnson 1999; Zeithaml et al. 1996). More recent studies have focused on explaining actual customer retention over time in these dyadic relationships. These studies generally reveal a positive effect of customer satisfaction on retention, although this effect might be nonlinear and/or moderated by customer characteristics (e.g., Bolton 1998; Mittal and Kamakura 2001).

A notable exception is the study of Mittal et al. (1999), which we will refer to as MKT hereafter. MKT draw on the theory of consumption systems to distinguish between a product system (i.e., car brand) and service system (i.e., dealer). Subsequently they investigate how consumers' satisfaction with the brand and the dealer impacts brand and dealer repurchase-intentions over time. They conclude that consumers' satisfaction with dealers positively affects brand repurchase intentions, but that this effect declines over time.

The present study extends the study of MKT in four ways. First, our study adopts the now dominant notion in marketing research that one should study actual switching behaviour instead of repurchase intentions (e.g., Bolton 1998; Mittal 
and Kamakura 2001). Therefore this study uses actual data on brand and dealer retention instead of repurchase intentions as MKT did.

Second, we investigate the moderating effect of brand tier. We include brand tier because the channel literature suggests that brand tier impacts the opportunities that dealers have to add value to the brand (Coughlan et al. 2001; Steiner 2004). For example, the high-tier (prestige) Mercedes brand is likely to reduce the dealer's contribution to brand loyalty, because Mercedes buyers value the brand's impact on their social network (Fournier 1998). With a low-tier (i.e., economy) brand, like Seat, the dealer is likely to play a more prominent role in shaping brand loyalty. This raises the question whether dealers selling different brands are uniformly successful in contributing to brand retention or that their influence varies across different brands. To accommodate the differential effects of dealers for different brands, we include brand tier as a moderator, building on previous literature that suggested that the effectiveness of marketing instruments may differ between brand or price tiers (e.g., Lemon and Nowlis 2002; Russell and Bolton 1988). To date no studies have empirically investigated this moderating role of brand tier.

Third, we emphasize the importance of strategic fit between the product (i.e., car brand) and the service (i.e., dealer) systems. As such we extend the strategy literature that has emphasized the importance of fit between strategy and governance structure in a retail setting (Yin and Zajac 2004). Likewise brand manufacturers seek a strategic fit between their brand and their dealers. Lexus dealers, for instance, have luxurious showrooms while Suzuki dealers have rather sober showrooms. The question arises whether this brand-dealer fit is also considered important by customers. To this end we will investigate whether brand tier moderates the effect that dealer quality and dealer payment equity have on dealer retention. In doing so we broaden the loyalty literature which has looked at the moderating effects of socio-demographics, consumer knowledge, switching costs, market characteristics and prior relationship duration (e.g., Bolton 1998; Mittal and Kamakura 2001; Seiders et al. 2005), but not at brand characteristics within a given market.

Fourth, we study a different institutional environment. The Dutch dealer system is, in comparison to the US, characterized by exclusive distribution (i.e., a dealer only sells one brand). This means that brand-disloyal customers are forced to switch to another dealer. Only brand-loyal customers have a real option to switch dealer. This typical European dealership structure may impact how dealers add value to consumers' brand retention decisions.

To accomplish these extensions over MKT we review the literature about the role of brand tier in consumers' brand and dealer retention decisions. We derive four hypotheses from theory and test them using behavioral and perceptual data of 922 new car buyers in The Netherlands. Brands are classified as prestige brands, volume brands or economy brands to investigate the moderating effect of brand tier. The estima- tion results of our nested logit model reveal that only volume brand dealers contribute to brand retention. The findings also show that the way in which dealers influence consumers' dealer retention decisions varies across brand tiers. Together these findings indicate that the role of the dealer in improving retention is more complex than previously assumed.

The remainder of the article is structured as follows. The second section discusses the institutional context of our study. The third section presents the theoretical background and our hypotheses. In the fourth section we present our econometric model. The fifth section discusses our methodology and sixth section presents our results. The seventh section discusses the implications of our results. The final section presents our study's limitations and directions for further research.

\section{Institutional context}

In the market for new cars consumers use the car and the associated services during an extended time period. During this period both the dealer and the brand influence consumers' brand and dealer perceptions. At the end of this period consumers decide whether to replace the car. The replacement of the product can result in the four outcomes: (1) brand retention and dealer retention, (2) brand retention and dealer defection, (3) brand defection and dealer retention, and (4) brand defection and dealer defection. The third outcome is not considered in this study because in the Dutch car market almost all dealers, with the exception of a small number of dealers associated with the Volkswagen Group (i.e., Audi, Volkswagen and Skoda), sell a single car brand. This means that customers switching brand are forced to switch dealer. Only customers loyal to the brand have a real option to switch to another dealer of that particular brand. This results in a loyalty decision tree as displayed in Fig. 1.

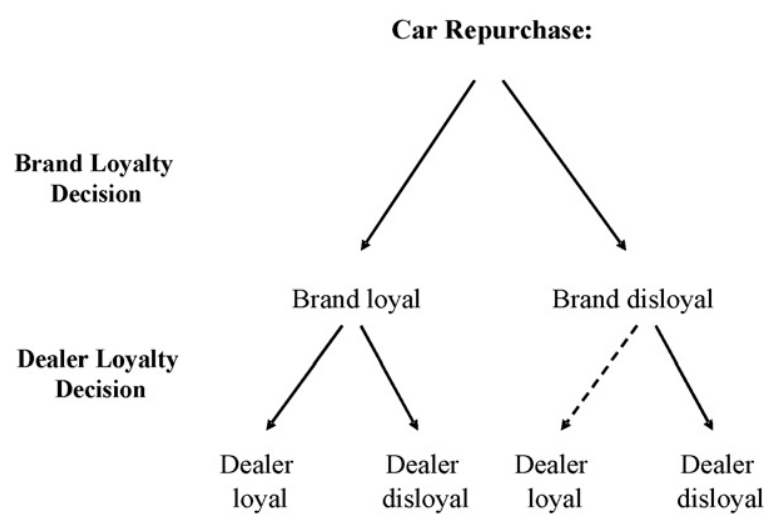

Note: ---- Choice is rare in the Dutch market for new cars and not considered in this study.

Fig. 1. Decision tree of brand and dealer retention decisions. 
Besides the institutional context there are other market characteristics that should be mentioned upfront. In a small and densely populated country like The Netherlands, dealers of the same brand are closely located to each other. The average number of dealers per brand is, according to the Dutch Dealer Association, about 100. If we relate this number to the country's size this means that each brand has about one dealer outlet per every $350 \mathrm{~km}^{2}$. This high dealer density implies that consumers only need to travel for about $20 \mathrm{~min}$ by car to visit another dealer. The dealer density varies however across the different brand tiers. We will address these differences in more detail as we discuss alternative model specifications in alternative model specifications section.

\section{Theoretical background}

Our study builds on the theory of consumption systems as developed by MKT. In the new car market the car provided by the manufacturer and the sales efforts and services offered by the dealer can be considered two subsystems of the car consumption system. In this system the pattern of consumption occurs in multiple episodes over time. Characteristic for the car consumption system is that product performance not only depends on consumers' continuous experience with the manufacturers' product (i.e., the car), but also on the associated periodic sales (i.e., once every 3 years) and service efforts (e.g., once a year) provided by the dealer. Thus the consumption systems perspective specifically argues that the interplay between the car and the dealer subsystems influences consumers' perceptions and behaviors.

\section{Brand retention and dealer retention}

This study assumes that consumers' dealer retention decisions are based on consumers' unobserved dealer value (or utility). This value is construed by consumers' perceptions of dealer-related variables, such as dealer intrinsic and extrinsic quality, dealer payment equity, dealer trust, dealer switching costs and consumers' prior ties with the dealer. Similarly, the brand retention decision is based on consumers' subjective value (or utility) of the brand. This value is construed by consumers' perceptions of brand-related variables, such as brand quality, brand payment equity, brand equity, brand trust, brand switching costs and consumers' prior ties with the brand. In line with the theory of consumption systems we further argue that dealers also contribute to brand retention through their sales and service efforts. Moreover we suggest that the dealer's contribution to brand retention is moderated by brand tier, that is, the contribution of the dealer to brand loyalty varies across different brand tiers. We additionally examine the moderating effect of brand tier on the effects of dealer quality (intrinsic and extrinsic) and dealer payment equity on dealer retention.

The brand and dealer-related variables that we include in our study are derived from prior research on the antecedents of brand and/or dealer retention (e.g., Bolton et al. 2004; Chaudhuri and Holbrook 2001; Rust et al. 2004; Zeithaml et al. 1996). With the exception of perceived switching costs and prior ties these antecedents have widely been studied in the retention literature. Perceived switching costs arise because consumers perceive economic switching costs (i.e., travel distance to another dealer) or psychological switching costs (i.e., uncertainty about changing brand or dealer). Research has shown that perceived switching costs positively impact loyalty intentions (Burnham et al. 2003). Prior ties with the brand and/or dealer may affect consumers' retention decisions as they can reflect consumers' inertia (Rust et al. 2004). Although we will include them in our econometric model, we do not formulate hypotheses with regard to the effect of the brand and dealer-related variables because their impact on retention has been widely studied (e.g., DeWulf et al. 2001; Sirohi et al. 1999). An overview of the variables included in our study is provided in Table 1.

\section{Hierarchy in brand retention and dealer retention}

This study assumes that consumers first decide to be (dis)loyal to the brand and subsequently decide to be (dis)loyal to the dealer. There are three reasons underlying this assumption. First, the theory of consumption systems postulates that consumers continuously experience the performance of the car and only periodically experience the services of the dealer (MKT). Second, the price paid for a new car stands out as the most obvious cost of owning and using a car. Third, consumer research suggests that consumers mostly focus on the branded product instead of the dealer service. This focus is due to the efforts of most car manufacturers to build a strong brand image to position themselves in the minds of consumers (Sullivan 1998).

\section{Three different brand tiers}

Several studies in low-involvement markets, such as the FMCG, make a distinction between different brand tiers or price-quality tiers (e.g., Lemon and Nowlis 2002; Russell and Bolton 1988). The car market is a high-involvement market, which requires us to consider more than the two brand tiers that are frequently considered in low-involvement markets. In the new car market we distinguish between three brand tiers: prestige brands, volume brands and economy (or price) brands (Edmonson 2003a,b; Kirmani et al. 1999; Park et al. 1991). Prestige brands, such as Mercedes, BMW and Lexus, are strong brands that are premium priced. These brands usually have a relatively low market share. Prestige brands are purchased to communicate wealth, status and exclusivity (Bagwell and Bernheim 1996; Park et al. 1991). Volume brands, like Volkswagen and Ford, are priced near the market average and have relatively high market shares. These brands serve the majority of the market. They are not purchased for their status or exclusivity, but for reasons such as value-formoney. Finally, economy brands, such as Suzuki, Kia and 
Table 1

Definition, source and measurement of variables

\begin{tabular}{ll}
\hline Construct & Definition and sources \\
\hline Brand quality (BQ) & The customers judgment about the quality of a \\
brand (Mittal et al. 1999; Parasuraman et al. 1985)
\end{tabular}

Brand equity (BE)

Brand switching cost (BSC)

Prior ties with the brand (BPT)

Intrinsic dealer quality (DIQ)

Extrinsic dealer quality (DEQ)

Dealer payment equity (DPE)
The consumer's awareness and image of the brand (cf. Keller 2003)

The customer's perceived costs of switching to a new brand (Heide and Weiss 1995; Weiss and Anderson 1992)

Indicates whether the customer has bought the same brand before (Rust et al. 2004)

The customer's judgment about the quality of a dealer regarding its intrinsic attributes (Mittal et al. 1999; Parasuraman et al. 1985)

The customer's judgment about the quality of a dealer regarding its extrinsic attributes (Mittal et al. 1999; Parasuraman et al. 1985)

The customer's perception of the fairness of the exchange of payment for the dealer's services (Bolton and Lemon 1999; Oliver and Swan 1989; Lichtenstein and Bearden 1989)
Measures

Likert scales $(1=$ very poor and $5=$ very good $)$

Functionality

Engine power

Comfort

Ease of use

Space

Safety

Design

Emanation

Model variety

Trimmings ${ }^{\mathrm{a}}$

Interior $^{\mathrm{b}}$

Likert scales $(1=$ very strongly disagree and $5=$ very strongly agree)

My [brand] was reasonably priced

The quality/price ratio of [brand] is good

[Brand] gives me my money's worth

The price of my [brand] was too high ${ }^{\mathrm{a}}$

Likert scales $(1=$ very strongly disagree and $5=$ very strongly agree)

I trust [brand]

I rely on [brand]

Likert scales $(1=$ very strongly disagree and $5=$ very strongly agree)

[Brand] is a strong brand

[Brand] is a well-known brand

[Brand] is an attractive brand ${ }^{\mathrm{a}}$

[Brand] is a unique brand

Likert scales $(1=$ very strongly disagree and $5=$ very strongly agree)

It is difficult to switch between car brands

It is troublesome to switch between car brands

Dummy variable created from information on past car ownership

Likert scales $(1=$ very poor and $5=$ very good $)$

Standing by agreements

Quality of maintenance

Quality of repairs

Quality of explanations with repairs

Quality of explanations with maintenance

Quality of communications

Ability to do things first time right

Craftsmanship $^{\mathrm{b}}$

Willingness to help you ${ }^{\mathrm{b}}$

Speed with which you are being served

Personal attention that you receive ${ }^{\mathrm{b}}$

Likert scales $(1=$ very poor and $5=$ very good $)$

Lay-out of the workshop

Atmosphere in the workshop

Lay-out of the showroom

Emanation of the showroom

Atmosphere in the showroom ${ }^{\mathrm{b}}$

Likert scales $(1=$ very strongly disagree and $5=$ very strongly agree)

Repairs at [dealer] are costly

[Dealer] gave me a good trade-in value for my old car

[Dealer] gives me my money's worth

The quality/price ratio with [dealer] is good 
Table 1 (Continued)

\begin{tabular}{|c|c|c|}
\hline Construct & Definition and sources & Measures \\
\hline & & $\begin{array}{l}\text { I think I paid too much for my [brand] at }[\text { dealer] } \\
\text { [Dealer] got more out of the deal than I did } \\
\text { The maintenance costs at [dealer] are too high }\end{array}$ \\
\hline Dealer trust (DT) & $\begin{array}{l}\text { The customer's willingness to rely on the ability of } \\
\text { the dealer to perform its stated function (Chaudhuri } \\
\text { and Holbrook 2001) }\end{array}$ & $\begin{array}{l}\text { Likert scales }(1=\text { very strongly disagree and } 5=\text { very } \\
\text { strongly agree }) \\
\text { I trust [dealer] } \\
\text { I rely on [dealer] }\end{array}$ \\
\hline Dealer switching cost (DSC) & $\begin{array}{l}\text { The customer's perceived costs of switching to a } \\
\text { new dealer (Heide and Weiss 1995; Weiss and } \\
\text { Anderson 1992). }\end{array}$ & $\begin{array}{l}\text { Likert scales ( } 1=\text { very strongly disagree and } 5=\text { very } \\
\text { strongly agree) } \\
\text { It is difficult to switch between dealers } \\
\text { It is troublesome to switch between dealers }\end{array}$ \\
\hline Prior ties with the dealer (BPT) & $\begin{array}{l}\text { Indicates whether the customer has purchased a car } \\
\text { from the same dealer before (Rust et al. 2004) }\end{array}$ & $\begin{array}{l}\text { Dummy variable created from information on the } \\
\text { customer's previous dealer relationships }\end{array}$ \\
\hline
\end{tabular}

\footnotetext{
${ }^{a}$ Deleted during further item purification.
}

${ }^{b}$ Deleted during initial item purification.

Hyundai, are weaker brands that are sold in the low-end of the market. These brands are priced below the market average. Not surprisingly, the most important reason for consumers to purchase brands in this tier is price.

\section{Hypotheses}

\section{Moderating effect of brand tier on the contribution of the dealer to brand retention}

The channel literature suggests that dealers contribute to brand retention through their value-adding channel activities (Coughlan et al. 2001). The rationale is that dealers contribute to brand loyalty because they add to the consumer's consumption experience through their marketing and service efforts. Along this line of reasoning MKT have shown that both car and service satisfaction positively affect consumers' intentions to repurchase the car brand. The effect of service satisfaction is however much smaller than the effect of product satisfaction.

The contribution of dealers to brand loyalty may not be as straightforward as the channel literature suggest. The power and brand equity literatures suggest that stronger brands generate more consumer pull, which reduces the role of the dealer in consumers' brand retention decisions. High-tier brands are expected to create more consumer pull than low-tier brands because of their higher brand strength. Although this reasoning has mostly been applied in the packaged consumer goods industry (e.g., Steiner 2004; Ailawadi 2001), it suggests that brand tier may moderate the contribution of the dealer to brand retention. For brands with a lot of consumer pull, such as prestige brands like Mercedes and BMW, the contribution of the dealer to brand retention should be smaller than for brands with less consumer pull, such as economy and volume brands. In other words, the contribution of the dealer to brand retention decreases with increasing brand strength.
We contend that consumer pull through brand strength is not the only characteristic that differentiates the three brand tiers. More important perhaps is that different brand tiers appeal to different consumer segments, and that consumers value different aspects in the brands within each of these tiers (DeSarbo and Manrai 1992). Most consumers buy prestige brands to advertise their wealth and achieve social status (Bagwell and Bernheim 1996). These consumers consider the resulting impact on their social network more important than consumers buying volume or economy brands. This role of the brand in consumers' purchase decisions is likely to reduce the contribution of the prestige brand dealer to brand retention. Another point is that prestige brands are usually of higher quality, relative to volume and economy brands, perhaps making it more difficult for dealers to contribute to brand retention. These consumer-based arguments reinforce the expectation from the power and equity literatures that the dealer's contribution to brand retention is smaller for prestige brands than for volume and economy brands.

We expect volume brands to be stronger brands than economy brands. From a power and brand equity perspective, one might argue therefore that dealers of volume brands have fewer opportunities to add value than dealers of economy brands. Moreover, given that economy brands are usually of lower quality, dealers may be able to add more value to the brand through their service efforts. However, the most important rationale for consumers to buy an economy brand is price. Economy brand buyers consider price so important that they search extensively for the best price deal when buying a new car, independent from the dealer's performance, and they do not value dealer efforts that increase price. In contrast, dealers of volume brands can contribute to brand retention better because consumers in this segment not only focus on price, but also on other product and service attributes. This creates more opportunities for the dealer to add value. Together these arguments suggest, in contrast to the power and brand equity 
literatures, that volume brand dealers have a more prominent role in shaping brand retention than dealers of the economy brands.

To summarize, the impact that brand tier has on the contribution of the dealer to brand retention is a complex issue. The power and equity literatures suggest that dealers of volume brands contribute more to brand retention than dealers of prestige brands. This expectation is reinforced when consumer segments and differences are taken into account. Power and equity theory also suggests that the contribution of economy brand dealers surpasses that of volume brand dealers. Arguments that take into account what consumers of economy and volume brands truly value, countervail against this expectation. We contend that in these brand tiers the consumer-based arguments prevail over those from the power and brand equity literatures (DeSarbo and Manrai 1992). Thus we hypothesize that:

Hypothesis 1. The dealer's positive contribution to brand retention is larger for volume brands than for (a) prestige brands and (b) economy brands.

\section{Moderating effect brand tier in dealer retention decision}

Besides a moderating effect of brand tier on the dealer's contribution to brand retention, we also expect that brand tier moderates the effects of dealer quality and payment equity on dealer retention. We focus on dealer quality and payment equity because the brand tiers differ most in their performance on these dimensions and consumers' perceptions of quality and price are considered pivotal determinants of shopping behavior and product choice (Zeithaml 1988).

The theory of consumption systems suggests that consumers perceive the dealer as representing the brand. This means that there should be a fit between the brand and the dealer (cf. Zajac et al. 2000). From a consumer perspective, brand-dealer fit is defined as the consumers' perception of the consistency between brand attributes and dealer attributes. The notion of fit has gained attention in the brand extension literature, which has shown that fit is important for consumers' evaluations of brand extensions (Keller and Aaker 1992). Research also shows that consumers' evaluation of a product depends on whether it is presented separately or jointly with other products. The evaluation of a superior product decreases when jointly presented with inferior products, relative to its evaluation if it had been presented separately. Inferior products benefit from being jointly presented with superior products (Hsee and Leclerc 1998). In concurrence we expect that the presentation of the brand by the dealer affects consumers' evaluations. As noted earlier each brand tier has different core attributes and consumers look for consistency between brand and dealer attributes. This notion of fit implies that the effects of dealer quality and payment equity on dealer retention should be different for the three brand tiers.
The literature on the differential effects of marketing instruments between brand tiers also suggests a potential moderating effect of brand tier. Russell and Bolton (1988) show, for instance, that the price elasticity is higher for higher-priced brands than for lower-priced brands. Lemon and Nowlis (2002) additionally find that high-tier brands benefit more than low-tier brands from price promotions, displays or feature advertising when these promotional tools are used by themselves. This advantage disappears when certain promotional tools are used in combination with one another. It is important to remember that both these studies discuss the moderating effect of marketing instruments on the brand level instead of the dealer level within the car consumption system.

\section{Intrinsic dealer quality}

Intrinsic dealer quality refers to the core service quality provided by dealers (e.g., quality of maintenance, speed of service) as experienced by the customer (Zeithaml 1988). MKT have shown that intrinsic dealer quality positively affects consumers' intentional loyalty to dealers. In line with this we assume a positive contribution of intrinsic dealer quality to dealer retention. The dealer's contribution is however likely to be different for the different brand tiers. Following the notion of brand-dealer fit high service quality should especially be important for dealers of prestige brands, because prestige brand customers are likely to have higher intrinsic quality expectations than consumers of economy and volume brands. A counterargument might be that high intrinsic dealer quality improves the car's functional performance. This means that consumers are likely to perceive intrinsic dealer quality as more (less) important for the functional performance of lower (higher) quality car brands. Economy brands have, relatively to volume and prestige brands, lower quality. Thus dealers of economy brand have more opportunities to "improve" the functional performance of the car itself. This suggests that intrinsic dealer quality should be more important for economy brands than for volume and prestige brands. Following the notion of brand-dealer fit we hypothesize that:

Hypothesis 2. The positive effect of intrinsic dealer quality on dealer retention is largest for prestige brands.

\section{Extrinsic dealer quality}

Extrinsic dealer quality refers to consumers' evaluations of the service environment (i.e., showroom). As such it is closely related to store atmosphere or environment (e.g., Grewal et al. 2003). The store environment influences consumers' perceptions of store choice criteria, such as quality and price, and these perceptions, in turn, affect patronage intentions (Baker et al. 2002). This line of reasoning suggests that to increase retention prestige brand dealers may aim to provide more experiential value in their service environment (Babin et al. 1994). Fitting up tasteful 
and luxury dealer showrooms may also stress the prestige brand's status (Bagwell and Bernheim 1996). In other words, to create a high brand-dealer fit dealers of prestige brands need to provide high extrinsic quality, otherwise consumers' evaluation of the brand and/or the dealer may decrease (Hsee and Leclerc 1998). Based on this line of reasoning we expect extrinsic dealer quality to have the largest impact on dealer retention for prestige brands. For economy brands high extrinsic dealer quality may signal that the dealer is not cost-efficient because the showroom cues are inconsistent with the brand cues (cf. Miyazaki et al. 2005). As such consumers might feel that they are paying too much for the dealer's services (Lam et al., 2004). This perceived misfit between the brand and the dealer is likely to harm dealer retention. Together these arguments suggest that:

Hypothesis 3. The positive effect of extrinsic dealer quality on dealer retention is (a) largest for prestige brands and (b) smallest for economy brands.

\section{Dealer payment equity}

Dealer payment equity is defined as consumers' perceived fairness of the price paid for dealers' products and services (Bolton and Lemon 1999). It can also be considered as the consumer's price perceptions of the dealer service (Bolton et al. 2004). Although empirical results are mixed, the literature assumes that payment equity positively affects retention (e.g., Verhoef 2003). A low price is the core attribute of economy brands. The notion of fit suggests that dealer payment equity is especially important for economy brand customers. For consumers of prestige brand payment equity seems less important. Prestige brands focus on status and image and lower payment equity may even reinforce branddealer fit. For prestige brands a lower price would signal a lower quality, bring on a brand-dealer misfit, and harm dealer retention. Moreover, prestige brand customers are generally less price-sensitive, willing and able to pay premium prices (Blattberg and Neslin 1990). Therefore it seems unlikely that payment equity is very important for prestige brand consumers. For volume brands the importance of payment equity is less clear. Price might be the only instrument that volume brand dealers can use to differentiate themselves from other dealers, so consumers might select their preferred dealer on this. At the same time, the notion of brand-dealer fit suggests that dealers of volume brands should have fair prices. Thus payment equity is important for volume brand customers. It will, however, not be as important as it is for economy brand customers, whose only focus is on price. Following the notion of brand-dealer fit we hypothesize that:

Hypothesis 4. The positive effect of dealer payment equity on dealer retention is (a) largest for economy brands and (b) smallest for prestige brands.

\section{Econometric model}

\section{Model formulation}

Our model builds on the assumed hierarchy in consumers brand and dealer retention decisions in which the brand choice precedes the dealer loyalty decision (see Fig. 1). At the same time dealer performance affects brand retention through the unobserved dealer value. The nested logit model matches this hierarchical nature of consumers retention decisions and the contribution of the dealer to brand retention. Within the nested logit model, each decision is modeled as a regular binomial logit model. The dealer retention decision (DRET) of consumer $i$ depends on the consumers perception of the dealer-related variables that drive dealer retention: dealer intrinsic quality (DIQ), dealer extrinsic quality (DEQ), dealer payment equity (DPE), dealer trust (DT), dealer switching costs (DSC), and prior ties with the dealer (DPT). We allow for the moderating effect of brand tier by estimating brand tier specific parameters for these variables. This is accomplished by including an interaction between the brand tier dummies (dummy prestige brands (DPRB), dummy volume brands (DVOB), and dummy economy brands (DECB)) and dealer intrinsic quality, and extrinsic quality, and payment equity respectively. We also include brand tier dummies as main effects. The dealer retention probability, given a consumer's decision to stay loyal to the brand $(\mathrm{BRET}=1)$, is mathematically formulated as

$$
\begin{aligned}
& P\left(\mathrm{DRET}_{i} \mid \mathrm{BRET}_{i}=1\right) P\left(U_{\mathrm{d}, i}^{*}>0\right) \\
& U_{\mathrm{d}, i}^{*}=U_{\mathrm{d}, i}+\varepsilon_{\mathrm{d}, i} \\
& U_{\mathrm{d}, i}=\beta_{0}+\beta_{1 \mathrm{p}} \mathrm{DPRB} \times \mathrm{DIQ}_{i}+\beta_{1 \mathrm{v}} \mathrm{DVOB} \times \mathrm{DIQ}_{i} \\
& +\beta_{1 \mathrm{e}} \mathrm{DECB} \times \mathrm{DIQ}_{i}+\beta_{2 \mathrm{p}} \mathrm{DPRB} \times \mathrm{DEQ}_{i} \\
& +\beta_{2 \mathrm{v}} \mathrm{DVOB} \times \mathrm{DEQ}_{i}+\beta_{2 \mathrm{e}} \mathrm{DECB} \times \mathrm{DEQ}_{i} \\
& +\beta_{3 \mathrm{p}} \mathrm{DPRB} \times \mathrm{DPE}_{i}+\beta_{3 \mathrm{v}} \mathrm{DVOB} \times \mathrm{DPE}_{i} \\
& +\beta_{3 \mathrm{e}} \mathrm{DECB} \times \mathrm{DPE}_{i}+\beta_{4} \mathrm{DT}_{i}+\beta_{5} \mathrm{DSC}_{i} \\
& +\beta_{6} \mathrm{DPT}_{i}+\beta_{7} \mathrm{DPRB}_{i}+\beta_{8} \mathrm{DVOB}_{i}
\end{aligned}
$$

$U_{\mathrm{d}, i}^{*}$ is usually interpreted as a latent utility that consumer $i$ associates with the dealer. The consumer then decides to stay loyal when $U_{\mathrm{d}, i}^{*}>0$. In our theoretical framework we have labeled this utility as the unobserved dealer value. $U_{\mathrm{d}, i}$ is the observed part of this and $\varepsilon_{\mathrm{d}, i}$ is a random unobservable component representing all unobserved components. When a Gumbel distribution is assumed for $\varepsilon_{\mathrm{d}, i}$, the familiar Logit model results, so

$$
P\left(\operatorname{DRET}_{i} \mid \mathrm{BRET}_{i}=1\right)=\frac{\exp \left(U_{\mathrm{d}, i}\right)}{1+\exp \left(U_{\mathrm{d}, i}\right)}
$$

In the nested logit framework the brand retention probability depends upon the expected utility obtained from the dealer. This expected utility reflects the contribution of the 
dealer to brand retention. This is usually referred to as the inclusive value component. Depending on the application this value has a specific content. For example, researchers modeling category purchase incidence and brand loyalty refer to this value as category value (Bucklin and Lattin 1991). Similarly, we refer to this inclusive value as dealer value (DV). Ben-Akiva and Lerman (1985) show that the natural logarithm of the denominator of the dealer retention probability in Eq. (4) equals DV. We allow for the hypothesized moderating effect of brand tier on dealer value by estimating brand tier specific parameters for these variables by including interactions between the brand tier dummies and dealer value. To model the brand retention decision of consumer $i$, we use the binomial logit model with dealer value and the brand-related variables, being brand quality (BQ), brand payment equity (BPE), brand trust (BT), brand equity (BE), brand switching costs (BSC), and prior ties with the brand (BPT), as predictors of brand retention. The mathematical formulation is as follows:

$$
\begin{aligned}
& P\left(\mathrm{BRET}_{i}=1\right)=P\left(U_{\mathrm{b}, i}^{*}>0\right) \\
& U_{\mathrm{b}, i}^{*}= U_{\mathrm{b}, i}+\varepsilon_{\mathrm{b}, i} \\
& U_{\mathrm{b}, i}= \theta_{0}+\theta_{1} \mathrm{BQ}_{i}+\theta_{2} \mathrm{BPE}_{i}+\theta_{3} \mathrm{BT}_{i}+\theta_{4} \mathrm{BE}_{i}+\theta_{5} \mathrm{BSC}_{i} \\
&+\theta_{6} \mathrm{BPT}_{i}+\theta_{7} \mathrm{DPRB}_{i}+\theta_{8} \mathrm{DVOB}_{i}+\tau_{0 \mathrm{p}} \mathrm{DPRB} \\
& \times \mathrm{DV}_{i}+\tau_{0 \mathrm{v}} \mathrm{DVOB} \times \mathrm{DV}_{i}+\tau_{0 \mathrm{e}} \mathrm{DECB} \times \mathrm{DV}_{i} \\
& \mathrm{DV}_{i}= \log \left(1+\exp \left(U_{\mathrm{d}, i}\right)\right)
\end{aligned}
$$

Similar to the dealer retention model, $U_{\mathrm{b}, i}^{*}$ is the consumers unobserved latent utility of the brand and $\varepsilon_{\mathrm{b}, i}$ is a random error term for the brand retention equation. The nested logit model is estimated using the maximum likelihood method. The likelihood for the nested logit model is given by

$$
\begin{aligned}
\ln L= & \sum_{i=1}^{n} \ln \left(1-\mathrm{BRET}_{i}\right) \times\left(1-P\left(\mathrm{BRET}_{i}=1\right)\right)+\mathrm{BRET}_{i} \\
& \times P\left(\mathrm{BRET}_{i}=1\right) \times\left(\mathrm{DRET}_{i} \times P\left(\mathrm{BRET}_{i}\right.\right. \\
& \left.=1 \mid \mathrm{BRET}_{i}=1\right)+\left(1-\mathrm{DRET}_{i}\right) \\
& \left.\times\left(1-P\left(\mathrm{DRET}_{i}=1 \mid \mathrm{BRET}_{i}=1\right)\right)\right)
\end{aligned}
$$

\section{Model and hypotheses}

The nested logit model that we specified above will be used to test our hypotheses. Hypothesis 1 states that the dealers positive contribution to brand retention is larger for volume brand than for (a) prestige brands and (b) economy brands. In terms of our model this would imply that: $\tau_{0 \mathrm{v}}>\tau_{0 \mathrm{p}}$, $\tau_{0 \mathrm{e}}$. Hypothesis 2 specifies that the positive effect of intrinsic dealer quality on dealer retention is largest for prestige brands. Expressed in our models specification this means that: $\beta_{1 \mathrm{p}}>\beta_{1 \mathrm{v}}, \beta_{1 \mathrm{e}}$. In Hypothesis 3 we specify that the positive effect of dealer extrinsic quality on dealer retention is (a) largest for prestige brands and (b) smallest for economy brands. Formulated in terms of our model this would connote that: $\beta_{2 \mathrm{p}}>\beta_{2 \mathrm{v}}>\beta_{2 \mathrm{e}}$. Finally, Hypothesis 4 states that the positive effect of dealer payment equity on dealer retention is (a) largest for economy brands and (b) smallest for prestige brands. Specified in terms of our model this would mean that: $\beta_{2 \mathrm{e}}>\beta_{2 \mathrm{v}}>\beta_{2 \mathrm{p}}$.

\section{Methodology}

\section{Data collection}

The Dutch Centre for Vehicle Technology and Information randomly provided the contact details of 4,291 consumers that privately bought a new car within the first 2 months of 2003. This centre issues and administers vehicle registration certificates of all cars in The Netherlands. Each consumer was contacted in the spring by telephone and asked to participate in the study. A total of 1,640 consumers were willing to cooperate (a response rate of 38.2 percent). To be eligible for participation consumers had to meet two criteria. First, they must have made a repurchase. Thus, we excluded first-time car purchases because we study brand retention. Second, they must have had their car regularly serviced and maintained at an official dealer selling and servicing that particular car brand. These selection criteria resulted in a reduced sample size of 999 consumers. These consumers were interviewed by phone using a standardized questionnaire. In answering the questions respondents were asked to primarily focus on the car brand that they recently traded-in and the dealer from which this car was bought and at which it was serviced. This resulted in a usable sample of 970 respondents ( 29 incomplete responses were excluded from the analysis). In the estimation of our econometric model, we also excluded 15 respondents who moved to another city or village and provided this as their main reason for dealer switching. The key sample characteristics with respect to age and education level are consistent with Dutch market studies on the characteristics of new car buyers.

\section{Measure development and pretesting}

We constructed a dichotomous variable that indicates brand retention by comparing the brand of the consumer's newly repurchased car with the brand of the car that the consumer previously owned. These brand switching details were obtained both from the database of the Centre for Vehicle Technology and Information and cross-checked by means of the survey data. Likewise, we established a dichotomous variable labeled dealer retention by comparing the dealer from which consumers purchased their new car with the dealer from which the previously owned car was purchased and serviced. Dealer switching behavior was obtained from the survey data. 
To measure the consumers perceptions with regard to the brand and dealer-related variables we generated a pool of 50 items for measuring each of the constructs using literature search and interviews with academics and consumers. Pretests of these items were performed in three phases: (1) face-to-face interviews with four academics, (2) interviews with four industry experts, and (3) a test of substantive validity involving four consumers. By the end of pretesting participants reported no concerns. The questionnaire was therefore ready for final administration.

The brand and dealer-related variables were measured using the multi-item scales shown in Table 1. The prior ties with the car brand was measured by asking if the respondent had purchased the same car brand before (i.e., before the purchase of the car traded in). A similar type of question was asked to measure the respondents prior ties with the dealer. This resulted in a dichotomous variable in which a 1 indicates prior ties and a 0 the absence of prior ties.

\section{Assessment of psychometric properties}

To purify the list of items of the multi-item scales we computed inter-item correlations and corrected item-to-total correlations for each item, taking one subscale at a time, to obtain unidimensionality. We eliminated items for which these correlations were not significant $(p<.01)$. Principal axis factoring explored the unidimensionality of each purified scale using an eigenvalue of 1.0 and factor loadings of 0.40 as the cut-off points. Computing reliability coefficients explored the reliability of each purified, unidimensional scale. Where the coefficient $\alpha$ was smaller than 0.7 , we removed the item with the lowest corrected item-to-total correlation until meeting the 0.7 level (Nunnally 1978). The deleted items are marked in Table 1.

To further refine the measures we used the reduced set of items to estimate two CFA models using ML-estimation in LISREL 8.3. The first CFA model included the items pertaining to the brand-related variables. The second model included the items pertaining to the dealer-related variables. The modification indices showed that the fit of both models could be improved by eliminating two items respectively. The deleted items are marked in Table 1. The results of the re-specified models, reported in Tables 2 and 3, indicate that the absolute (i.e., GFI and NFI) and relative (i.e., NNFI, CFI and IFI) fit indices are at or above the threshold value of 0.90 . The parsimonious fit measures (i.e., $\chi^{2} / d f$ ) are 4.17 and 3.42, respectively, well within the acceptable range of two to five. The RMSEAs are below the recommended 0.08 level. In both models the composite reliabilities exceed the 0.70 threshold for acceptable reliability (Bagozzi and Yi 1988) and the majority of the average values for extracted variance exceed the threshold level of 0.50 . Convergent validity was indicated by the fact that in each model all items significantly load $(t>2.0)$ on their corresponding latent construct.

Table 2

Results confirmatory factor analysis brand variables $(n=970)$

\begin{tabular}{|c|c|c|c|c|c|}
\hline & SE & $t$-Value & $\mathrm{AEV}$ & Composite reliability & Coefficient $\alpha$ \\
\hline \multicolumn{6}{|l|}{ Brand quality } \\
\hline Functionality & 0.72 & 24.86 & 0.45 & 0.88 & 0.88 \\
\hline Engine power & 0.68 & 23.14 & & & \\
\hline Comfort & 0.59 & 19.20 & & & \\
\hline Ease of use & 0.66 & 22.04 & & & \\
\hline Space & 0.65 & 21.72 & & & \\
\hline Safety & 0.75 & 26.43 & & & \\
\hline Design & 0.69 & 23.60 & & & \\
\hline Emanation & 0.67 & 22.40 & & & \\
\hline Model variety & 0.60 & 19.76 & & & \\
\hline \multicolumn{6}{|l|}{ Brand payment equity } \\
\hline My [brand] was reasonably priced & 0.54 & 16.05 & 0.46 & 0.72 & 0.71 \\
\hline The quality/price ratio of brand is good & 0.69 & 21.53 & & & \\
\hline [Brand] gives me my money's worth & 0.79 & 25.11 & & & \\
\hline \multicolumn{6}{|l|}{ Brand trust } \\
\hline I trust [brand] & 0.85 & 19.87 & 0.55 & 0.73 & n.a. \\
\hline I rely on [brand] & 0.61 & 16.19 & & & \\
\hline \multicolumn{6}{|l|}{ Brand equity } \\
\hline$[$ Brand $]$ is a strong brand & 0.66 & 20.80 & 0.45 & 0.70 & 0.70 \\
\hline [Brand] is a well known brand & 0.73 & 23.63 & & & \\
\hline [Brand] is a unique brand & 0.62 & 19.94 & & & \\
\hline \multicolumn{6}{|l|}{ Brand switching costs } \\
\hline It is difficult to switch between car brands & 0.80 & 18.77 & 0.64 & 0.76 & n.a. \\
\hline It is troublesome to switch between car brands & 0.74 & 17.91 & & & \\
\hline
\end{tabular}

Model fit: $\chi^{2} / d f=4.17 ; \mathrm{GFI}=0.93 ; \mathrm{AGFI}=0.91 ; \mathrm{NFI}=0.901 ; \mathrm{NNFI}=0.91 ; \mathrm{CFI}=0.92 ; \mathrm{IFI}=0.92 ; \mathrm{RMSEA}=0.059$. 
Table 3

Results confirmatory factor analysis dealer variables $(n=970)$

\begin{tabular}{|c|c|c|c|c|c|}
\hline & SE & $t$-Value & $\mathrm{AEV}$ & Composite reliability & Coefficient $\alpha$ \\
\hline \multicolumn{6}{|l|}{ Intrinsic quality dealer } \\
\hline Lay-out of the workshop & 0.77 & 19.16 & 0.68 & 0.89 & 0.88 \\
\hline Atmosphere in the workshop & 0.78 & 19.57 & & & \\
\hline Lay-out of the showroom & 0.86 & 22.57 & & & \\
\hline Emanation of the showroom & 0.88 & 23.59 & & & \\
\hline \multicolumn{6}{|l|}{ Extrinsic quality dealer } \\
\hline Standing by agreements & 0.73 & 18.08 & 0.62 & 0.92 & 0.92 \\
\hline Quality of maintenance & 0.77 & 19.62 & & & \\
\hline Quality of repairs & 0.80 & 20.60 & & & \\
\hline Quality of explanations with repairs & 0.81 & 21.32 & & & \\
\hline Quality of explanations with maintenance & 0.76 & 19.25 & & & \\
\hline Quality of communications & 0.83 & 21.80 & & & \\
\hline Ability to do things first time right & 0.81 & 20.87 & & & \\
\hline \multicolumn{6}{|l|}{ Dealer payment equity } \\
\hline Repairs at [dealer] are costly & 0.68 & 16.08 & 0.53 & 0.71 & 0.79 \\
\hline [Dealer] gave me a good trade-in value for my old car & 0.61 & 13.74 & & & \\
\hline [Dealer] gives me my money's worth & 0.85 & 22.15 & & & \\
\hline The quality/price ratio with [dealer] is good & 0.76 & 18.46 & & & \\
\hline \multicolumn{6}{|l|}{ Dealer trust } \\
\hline I trust [dealer] & 0.85 & 17.69 & 0.52 & 0.71 & n.a. \\
\hline I rely on [dealer] & 0.57 & 10.25 & & & \\
\hline \multicolumn{6}{|l|}{ Dealer switching costs } \\
\hline It is difficult to switch between dealers & 0.69 & 18.62 & 0.63 & 0.81 & n.a. \\
\hline It is troublesome to switch between dealers & 0.89 & 23.15 & & & \\
\hline
\end{tabular}

Model fit: $\chi^{2} / d f=3.42 ; \mathrm{GFI}=0.89 ; \mathrm{AGFI}=0.87 ; \mathrm{NFI}=0.91 ; \mathrm{NNFI}=0.92 ; \mathrm{CFI}=0.94 ; \mathrm{IFI}=0.94 ; \mathrm{RMSEA}=0.076$.

Table 4

Correlation matrix $(n=970)$

\begin{tabular}{|c|c|c|c|c|c|c|c|c|c|c|c|c|c|c|}
\hline & $\begin{array}{l}\text { No. of items } \\
\text { remaining }\end{array}$ & $\begin{array}{l}\text { No. of items } \\
\text { deleted }^{\mathrm{a}}\end{array}$ & Mean & $S D$ & 1. & 2. & 3. & 4. & 5. & 6. & 7. & 8. & 9. & 10. \\
\hline 1. Brand quality & 9 & 2 & 4.14 & 0.52 & 1.00 & & & & & & & & & \\
\hline 2. Brand payment equity & 3 & 1 & 4.00 & 0.77 & 0.31 & 1.00 & & & & & & & & \\
\hline 3. Brand trust & 2 & 0 & 4.21 & 0.87 & 0.33 & 0.43 & 1.00 & & & & & & & \\
\hline 4. Brand equity & 3 & 1 & 3.97 & 0.70 & 0.47 & 0.45 & 0.42 & 1.00 & & & & & & \\
\hline 5. Brand switching costs & 2 & 0 & 2.46 & 1.35 & 0.13 & 0.13 & 0.06 & 0.20 & 1.00 & & & & & \\
\hline 6. Intrinsic quality dealer & 7 & 4 & 3.95 & 0.75 & 0.35 & 0.30 & 0.24 & 0.30 & 0.10 & 1.00 & & & & \\
\hline 7. Extrinsic quality dealer & 4 & 1 & 4.07 & 0.77 & 0.36 & 0.35 & 0.37 & 0.33 & 0.14 & 0.57 & 1.00 & & & \\
\hline 8. Dealer payment equity & 4 & 3 & 3.64 & 0.86 & 0.30 & 0.44 & 0.37 & 0.36 & 0.18 & 0.43 & 0.62 & 1.00 & & \\
\hline 9. Dealer trust & 2 & 0 & 3.95 & 1.02 & 0.23 & 0.27 & 0.38 & 0.23 & 0.09 & 0.35 & 0.61 & 0.54 & 1.00 & \\
\hline 10. Dealer switching costs & 2 & 0 & 2.30 & 1.32 & 0.10 & 0.12 & 0.07 & 0.20 & 0.71 & 0.17 & 0.15 & 0.21 & 0.09 & 1.00 \\
\hline
\end{tabular}

a The deleted items are marked in Table 1.

We assessed the discriminant validity across the subscales by estimating two-factor models for each possible pair of subscales twice: once constraining the correlation between the latent variables to unity, and once freeing the parameter. We used a chi-square difference test to assess whether the chisquare of the unconstrained model was significantly lower $(p<.05)$ than that of the constrained model as evidence of discriminant validity. This procedure indicates discriminant validity between all pairs of constructs. Table 4 shows the means, standard deviations and inter-construct correlations. Together the results of the tests indicated a sufficient degree of unidimensionality, reliability and validity. Based on this evidence we formed the constructs by averaging the responses to each item.

\section{Classification of brand tiers}

For the classification of the brands into the three brand tiers we asked a separate sample of randomly selected Dutch consumers to classify 28 brands as either economy, volume or prestige brands. Each brand was classified by 62 consumers. The 28 brands in this classification study were the brands that the respondents in the survey mentioned as the brands of the cars they traded-in. To assess the reliability of the consumers judgments we used the proportional reduction in loss (PRL) approach (Rust and Cooil 1994). The results in Appendix A show that the PRL-reliability measure of 0.99 is well above the 0.70 threshold for acceptable reliability (Rust and Cooil 1994). This indicates that the assignment of brands to the dif- 
Table 5

Switching figures per brand tier

\begin{tabular}{|c|c|c|c|c|}
\hline Consumer is & $\begin{array}{l}\text { All brands }(n=968) \\
\text { (percent) }\end{array}$ & $\begin{array}{l}\text { Price brands }(n=168) \\
\text { (percent) }\end{array}$ & $\begin{array}{l}\text { Volume brands }(n=732) \\
\text { (percent) }\end{array}$ & $\begin{array}{l}\text { Prestige brands }(n=68) \\
\text { (percent) }\end{array}$ \\
\hline Brand and dealer loyal & 47.3 & 40.0 & 50.8 & 29.5 \\
\hline Brand loyal dealer disloyal & 13.3 & 16.3 & 12.8 & 11.5 \\
\hline Brand disloyal and dealer loyal & 3.4 & 4.4 & 3.1 & 3.8 \\
\hline Brand and dealer disloyal & 36.0 & 39.4 & 33.2 & 55.1 \\
\hline
\end{tabular}

Table 6

Estimation results nested logit model with moderating effect of brand tier $(n=922)$

\begin{tabular}{|c|c|c|c|c|c|}
\hline \multicolumn{3}{|l|}{ Dealer retention (Eq. (3)) } & \multicolumn{3}{|l|}{ Brand retention (Eq. 7) } \\
\hline Variable & Coefficient & Estimate & Variable & Coefficient & Estimate \\
\hline Constant & $\beta_{0}$ & $-2.51(1.46)$ & Constant & $\theta_{0}$ & $-6.46^{\mathrm{a}}(0.79)$ \\
\hline Dealer intrinsic quality $\times$ prestige brand & $\beta_{1 \mathrm{p}}$ & $-3.16(1.61)$ & Brand quality & $\theta_{1}$ & $0.50^{\mathrm{a}}(0.19)$ \\
\hline Dealer intrinsic quality $\times$ volume brand & $\beta_{1 \mathrm{v}}$ & $-0.04(0.19)$ & Brand payment equity & $\theta_{2}$ & $0.24^{\mathrm{b}}(0.12)$ \\
\hline Dealer intrinsic quality $\times$ economy brand & $\beta_{1 \mathrm{e}}$ & $0.29(0.34)$ & Brand equity & $\theta_{3}$ & $0.23(0.14)$ \\
\hline Dealer extrinsic quality $\times$ prestige brand & $\beta_{2 \mathrm{p}}$ & $3.19(1.90)$ & Brand trust & $\theta_{4}$ & $0.41^{\mathrm{a}}(0.11)$ \\
\hline Dealer extrinsic quality $\times$ volume brand & $\beta_{2 \mathrm{v}}$ & $0.16(0.22)$ & Brand switching costs & $\theta_{5}$ & $0.21^{\mathrm{a}}(0.07)$ \\
\hline Dealer extrinsic quality $\times$ economy brand & $\beta_{2 \mathrm{e}}$ & $-0.98^{\mathrm{b}}(0.48)$ & Brand prior ties & $\theta_{6}$ & $0.57^{\mathrm{a}}(0.18)$ \\
\hline Dealer payment equity $\times$ prestige brand & $\beta_{3 p}$ & $-1.14(0.65)$ & Dummy prestige brand & $\theta_{7}$ & $0.57(0.70)$ \\
\hline Dealer payment equity $\times$ volume brand & $\beta_{3 \mathrm{v}}$ & $0.34(0.18)$ & Dummy volume brand & $\theta_{8}$ & $0.40(0.52)$ \\
\hline Dealer payment equity $\times$ economy brand & $\beta_{3 \mathrm{e}}$ & $0.91^{\mathrm{b}}(0.45)$ & Prestige brand $\times$ dealer value & $\tau_{0 \mathrm{p}}$ & $-0.49(0.31)$ \\
\hline Dealer trust & $\beta_{4}$ & $0.65^{\mathrm{a}}(0.13)$ & Volume brand $\times$ dealer value & $\tau_{0 \mathrm{v}}$ & $0.36^{\mathrm{a}}(0.15)$ \\
\hline Dealer switching costs & $\beta_{5}$ & $0.16(0.09)$ & Economy brand $\times$ dealer value & $\tau_{0 \mathrm{e}}$ & $0.15(0.29)$ \\
\hline Dealer prior ties & $\beta_{6}$ & $0.45^{\mathrm{b}}(0.23)$ & & & \\
\hline Dummy prestige brand & $\beta_{7}$ & $5.03(3.62)$ & & & \\
\hline Dummy volume brand & $\beta_{8}$ & $-1.00(1.71)$ & & & \\
\hline
\end{tabular}

Model statistics: Log likelihood $=-757.71 ;$ AIC $=1.702$, Notes. Standard errors in parentheses below coefficient.

${ }^{\mathrm{a}} p<.01$.

${ }^{\mathrm{b}} p<.05$.

ferent brand tiers is reliable. The validity of the classification was assessed by comparing it to the classification used by the Dutch Dealer Association. The two classifications were, with the exception of one brand, identical, confirming the validity of our brand tier classification. ${ }^{1}$

\section{Empirical results}

\section{Brand and dealer retention rates}

Of the consumers within our sample: (1) 47.3 percent is brand loyal and dealer loyal, (2) 13.3 percent is brand loyal and dealer disloyal, (3) 36.0 percent is brand disloyal and dealer disloyal, and (4) 3.4 percent is brand disloyal and dealer loyal. The small percentage of brand disloyal and dealer loyal consumers reflects the distribution structure in the Dutch car market. We decided to remove these consumers from the analysis. This resulted in a final sample of 922 consumers. The differences in switching patterns across the three brand tiers are shown in Table 5. What stands out is the relatively high percentage of prestige brand customers disloyal to both the brand and the dealer.

\footnotetext{
1 We also estimated our model without the brand that was classified differently in comparison to the classification used by the Dutch Dealer Association. The results were similar to the ones reported in the results section.
}

\section{Nested logit model results}

The parameter estimates of our model are reported in Table $6 .^{2}$ The results show that dealer intrinsic quality has no effect on dealer retention across all brand tiers. Thus we find no support for Hypothesis $2 .{ }^{3}$ Dealer extrinsic quality has a negative effect for economy brands $\left(\beta_{2 \mathrm{e}}=-0.98 ; p=.04\right)$. No significant effects are found for volume or prestige brands. A Wald Test reveals that the three coefficients significantly differ from each other $(p=.02)$. Pair-wise Wald Tests reveal that the coefficient for economy brands is significantly smaller than those for prestige brands and volume brands

\footnotetext{
${ }^{2}$ Consumer characteristics affect thresholds for switching (Mittal and Kamakura 2001). To test for such thresholds we also included consumer characteristics as antecedent of both brand and dealer retention in our model. No significant effects were found. One explanation might be our limited sample size in comparison to Mittal and Kamakura's (2001) study. Another explanation might be that we included additional variables in our model, such as brand equity, dealer trust, and, in particular, dealer switching costs.

${ }^{3}$ One explanation for the insignificant, yet negative sign of dealer intrinsic quality for prestige and volume brands might be multicollinearity. To asses this we also estimated models in which we excluded payment equity and dealer extrinsic quality. We also estimated separate dealer retention equations for each brand tier. Without exception the sign remained negative, making multicollinearity an unlikely explanation. Another explanation might be that consumers have different expectations with regard to dealer intrinsic quality for brands in different tiers. The delivered services of dealers might exceed the expectations of economy brand buyers, but no those of prestige and volume brand buyers. Clearly more research is needed to explain the negative signs.
} 
( $p=.01$ ). Thus, we find support for Hypothesis $3 b$. The coefficient of prestige brands is largest, but not significantly different from that of volume and economy brands. Thus we find no statistical support for Hypothesis $3 \mathrm{a}$.

With respect to dealer payment equity we find a positive effect for economy brands $\left(\beta_{3 \mathrm{e}}=0.91 ; p=.04\right)$ and no significant effects of prestige brands and volume brands. A Wald Test reveals unequal coefficients for the three brand tiers $(p=.03)$. Additional pair-wise Wald Tests show that the coefficient for prestige brands is significantly smaller than for volume $(p=.01)$ and economy brands $(p=.00)$. Therefore Hypothesis $4 \mathrm{~b}$ is supported. No significant difference is found between the coefficients of volume and economy brands. Thus there is no support for Hypothesis 4a. For the other antecedents of dealer retention we find expected positive effects of dealer trust $\left(\beta_{4}=0.65 ; p<.01\right)$ and prior ties with the dealer $\left(\beta_{6}=0.45 ; p<.05\right)$. Surprisingly, no significant effect is found for dealer switching costs.

In the brand retention equation, we are particularly interested in how the effect of dealer value on brand retention differs across the brand tiers. Our results reveal a nonsignificant effect of dealer value for prestige brands, a positive effect for volume brands $\left(\tau_{0 \mathrm{v}}=0.36\right.$; $p=.01$ ) and a nonsignificant effect of dealer value for economy brands. Based on a Wald Test we conclude that there are significant differences between the coefficients of the brand tiers $(p=.03)$. A pair-wise Wald Test reveals a significant negative difference between prestige and volume brands $(p=.01)$. This means that we find support for Hypothesis 1a. No significant differences are found between volume and economy brands $(p=.13)$ and prestige and economy brands $(p=.12)$. Thus, there is no support for Hypothesis $1 b$.

In the brand retention equation we find expected positive effects of brand quality $\left(\theta_{1}=0.50 ; p<.01\right)$, brand payment equity $\left(\theta_{2}=0.24 ; p<.05\right)$, brand trust $\left(\theta_{4}=0.41 ; p<.01\right)$, brand switching costs $\left(\theta_{5}=0.21 ; p<.01\right)$ and prior brand ties $\left(\theta_{6}=0.57 ; p<.01\right)$. Brand equity has no significant effect on brand retention. The dummies for the brand tiers are also not significant.

\section{Alternative model specifications}

In this section we discuss a number of alternative model specifications. We do not discuss the estimation results in detail, but focus on the model selection criteria presented in Table 7. The theoretical and conceptual foundation of our model, in combination with its good fit, supports the model we used for testing our hypotheses. This model serves as our benchmark model (specification 0) to compare alternative model specifications.
We start with the analysis of more restrictive specifications than ours. The first alternative specification excludes the brand tier interactions. The second specification additionally excludes the brand tier main effects. Both alternative specifications are rejected in favor of our benchmark model with main and interaction effects of brand tier. In our benchmark model we focus on the moderating effect of brand tier on the relationship between dealer quality, payment equity and dealer retention. Although we did not find theoretical and/or conceptual arguments for additional moderating effects of brand tier, we explore two specifications that include more interactions with brand tier. Specification three includes interactions between brand tier and all dealer-related variables in the dealer retention equation and specification four allows all effects in the brand retention equation to be brand-tier specific. Obviously the larger number of parameters in these models increases the log likelihood, but the improvements are nonsignificant according to the LR-Test and the AIC also increases. Inclusion of these additional interaction effects does not substantively affect our estimates, although some significance levels are slightly lower. To summarize, our benchmark model seems to incorporate all relevant brand tier interactions.

The benchmark model we used is a nested logit model in which the brand retention decision precedes the dealer retention decision. To validate our approach we also specified a nested logit model with a reversed decision order (specification 5) and a multinomial choice model (specification 6). Both models yield a higher AIC value. Thus our benchmark model provides a better fit versus parsimony. Because of the different structure the models are not nested, so the LR-Test is not a valid tool for model comparison.

\section{Alternative theoretical model specifications}

The power and brand equity theory suggests that brand equity might also be used as a moderator instead of brand tier. In line with Sloot et al. (2005) we collected brand equity evaluations for each brand among the same sample of Dutch consumers that performed the brand classification task. We measured brand equity using three items pertaining to the perceived status, quality and image of the brand. The coefficient $\alpha$ was 0.98 . We entered the average brand equity score for each brand in our database. These scores were used as a brand equity moderator. We still included a main effect of brand equity in the brand- and dealer retention equation using the survey data, but removed all brand tier dummies and interactions. The resulting model fit (specification 7) is worse than the fit of our benchmark model. More importantly, no significant main and interaction effects are found. We also tested another model in which we use the

Table 7

Model fit of alternative specifications

\begin{tabular}{lllr}
\hline Model specification & Log likelihood & $p$-Value LR-Test vs. benchmark & AIC \\
\hline 0. Benchmark (our proposed model) & -757.71 & - & 1.702 \\
1. No brand tier interactions (only main effects) & -767.68 & $0.031^{\mathrm{a}}$ & 1.706 \\
2. No brand tier effects & -777.71 & $0.000^{\mathrm{a}}$ & 1.720 \\
3. All effects in dealer loyalty equation brand-tier specific & -755.33 & $0.570^{\mathrm{b}}$ & 1.710 \\
4. All effects brand-tier specific & -749.43 & $0.551^{\mathrm{b}}$ & 1.724 \\
5. Reversed nesting in logit model & -765.09 & $-^{\mathrm{c}}$ & 1.718 \\
6. Multinomial logit model & -769.97 & $-\mathrm{c}$ & 1.722 \\
7. Model with brand equity per brand as moderator & -770.85 & $-{ }^{\mathrm{c}}$ & 1.725 \\
8. Model with brand equity per customer as moderator & -768.68 & $-\mathrm{c}$ & 1.729 \\
9. Model with number of dealers per brand as moderator & -775.90 & $-^{\mathrm{c}}$ & 1.728 \\
\hline
\end{tabular}

\footnotetext{
${ }^{\text {a }}$ Restricted model rejected in favor of our model.

b Our model not rejected in favor of more general model.

${ }^{c}$ Models are not nested (LR-Test not valid).
} 
brand equity score per customer (BE), based on the survey data, as a moderator (specification 8). The brand equity per customer is in our benchmark model only used as an antecedent of brand retention. The fit of this alternative model is worse than our benchmark model. We do however find a significant interaction between brand equity per customer and extrinsic dealer quality $(p<.05)$. Based on these estimation results we conclude that the use of brand tier as moderator, instead of brand equity, yields the better results. A final alternative specification includes the number of dealerships per brand as a moderator (specification 9). In the Dutch market prestige, economy and volume brands have, on average, 72.5, 75.6 and 128.3 dealers per brand respectively. These differences might suggest that consumers of prestige and economy brands face higher dealer switching costs than consumers of volume brands. These higher costs should enable them to contribute more to brand retention than volume brand dealers. However, the fact that consumers are more locked-in might discourage prestige and economy dealers to do so. Alternatively, it might be that volume dealers need to differentiate on service more. The fit results of the model including the number of dealerships is however worse than our benchmark model. Moreover, in this alternative model we only find a significant positive main effect of the number of dealerships on brand retention.

\section{Discussion and implications}

\section{Summary}

In this study we aimed to understand the brand and dealer retention decisions in the new car market. To this end we investigated how brand tier moderates the contribution of the dealer to brand retention, and how brand tier moderates the impact of dealer quality and payment equity on dealer retention. Table 8 summarizes our results.

\section{Discussion}

This study contributes to different theories: (1) consumption and service systems, (2) customer retention, (3) channel, power and equity, and (4) strategic fit and brand fit. We will discuss our contribution in relation to each literature stream.

\section{Consumption and service systems}

MKT introduced the theory of consumption and service subsystems. We have extended their theory in several ways. First, their study assumes that the influence of the dealer service subsystem on the (product) system is prevalent for all brands. Our results show that this influence is only significant for volume brands. Dealers selling prestige and economy brands seem to be in a position where they cannot contribute to brand retention. Thus our research provides pivotal knowledge in the sense that the contribution of the dealer to brand retention is dependent on brand tier.

Second, the proposed model by MKT focuses on product and dealer satisfaction as predictors of loyalty intention. We have also incorporated other independent variables, such as payment equity and trust, in both subsystems. Many of these variables are significant predictors of either dealer or brand retention. These findings indicate that it is important to include these variables in research aimed at multiple subsystems.

Third, our study incorporated behavioral instead of intentional loyalty. Therefore we used a different modeling approach in comparison to MKT. Our nested logit model eloquently models the contribution of the dealer to brand retention. We have tested this model against several other specifications, and shown that the fit of our model is superior.

Fourth, our study contributes to the theoretical development of the dealer (service) subsystem by showing that the effect of extrinsic dealer quality and dealer payment equity differs between brand tiers. High extrinsic quality has a harmful effect on dealer retention for economy brands and dealer payment equity a reinforcing effect. These findings are consistent with the notion of brand-dealer fit. The notion of brand-dealer fit is an important new notion for the consumption and service system theory, because it emphasizes that the impact of dealer instruments on dealer retention depends on the brand tier in the product subsystem.

Fifth, we studied brand and dealer retention decisions in another institutional environment, which is characterized by exclusive distribution. The study of MKT was executed in the US were brand switching without dealer switching is much more common. This shows that it is important to incorporate the institutional context in brand and dealer retention studies.

\section{Customer retention literature}

We contribute to the customer retention literature in two ways. First, we show that focusing on dyadic relationships is not sufficient to develop a comprehensive understanding of retention when customers have relationships with both the brand manufacturer and the dealer of that particular brand. In

Table 8

Summary of hypotheses and test results

\begin{tabular}{|c|c|c|}
\hline Hypothesis & $\begin{array}{l}\text { Directionally } \\
\text { supported }\end{array}$ & $\begin{array}{l}\text { Statistically } \\
\text { significant }\end{array}$ \\
\hline \multirow{2}{*}{$\begin{array}{l}\text { 1. The dealer's positive contribution to brand retention is larger for volume brands than for (a) prestige brands } \\
\text { and (b) economy brands }\left(\tau_{0 \mathrm{v}}>\tau_{0 \mathrm{p}}, \tau_{0 \mathrm{e}}\right)\end{array}$} & Yes (a) & Yes (a) \\
\hline & Yes (b) & No (b) \\
\hline 2. The positive effect of intrinsic dealer quality on dealer retention is largest for prestige brands $\left(\beta_{1 \mathrm{p}}>\beta_{1 \mathrm{v}}, \beta_{1 \mathrm{e}}\right)$ & No & No \\
\hline \multirow{2}{*}{$\begin{array}{l}\text { 3. The positive effect of extrinsic dealer quality on dealer retention is (a) largest for prestige brands and (b) } \\
\text { smallest for economy brands }\left(\beta_{2 \mathrm{p}}>\beta_{2 \mathrm{v}}>\beta_{2 \mathrm{e}}\right)\end{array}$} & Yes (a) & No (a) \\
\hline & Yes (b) & Yes (b) \\
\hline \multirow{2}{*}{$\begin{array}{l}\text { 4. The positive effect of dealer payment equity on dealer retention is (a) largest for economy brands and (b) } \\
\text { smallest for prestige brands }\left(\beta_{2 \mathrm{e}}>\beta_{2 \mathrm{v}}>\beta_{2 \mathrm{e}}\right)\end{array}$} & Yes (a) & No (a) \\
\hline & Yes (b) & Yes (b) \\
\hline
\end{tabular}


line with MKT our results show that in studying brand retention, the dealer retention decision must be taken into account. More importantly, our findings reveal that the dealer retention decision is nested within the brand retention decision.

Second, we have included brand tier as a moderator in our dealer retention model. Our results confirm the relevance of looking at brand tier as a moderator. Although the inclusion of brand tier as a moderator is in line with prior research, our results are different. We show that payment equity is important for economy brands. The results of studies by Russell and Bolton (1988) and Lemon and Nowlis (2002) indicate that the price elasticity should be smaller for economy brands. This opposite effect might be explained by differences in the research context (i.e., package goods vs. new car market) and the notion of brand-dealer fit. In our study the dealer service and brand are interlinked through the notion of fit. If the economy brand dealer is charging high service prices a misfit occurs between the price image of the brand and the dealer. This misfit increases consumers' price sensitivity towards the dealer.

\section{Channel, power and equity literatures}

Our study also contributes to the literatures which suggest that dealers are less powerful when they sell brands that induce a strong consumer pull. This would imply that dealers selling strong brands have fewer opportunities to contribute to brand retention. This line of reasoning needs to be fine-tuned in the context of our study because only dealers of volume brands significantly contribute to brand retention. One the one hand we find an opposing effect by revealing that dealers of economy brands, usually low-equity, do positively, albeit not significantly, contribute to brand retention. On the other hand our results show that the contribution of the dealer of prestige brands, usually high equity, to brand retention is smallest. This finding is consistent with the channel, power and equity literatures.

To be more convinced about our findings we also tested competing models with brand equity per brand and per customer as a moderator. The worse fit of these models reinforces our belief that brand tier matters most. Brand tier is a broader concept then brand equity because it takes both brand equity and consumer segment differences into account. For different brand tiers either consumer segment characteristics or brand equity might be more important. This explains our finding that economy brand customers value low prices (i.e., consumer difference) and customers of prestige brand customer value high brand equity. Clearly more in-depth research is required on this issue.

\section{Strategic and brand fit literature}

In our study we extend the strategic fit and brand extension literatures by introducing the concept of brand-dealer fit. This notion can be used to explain the difference in the importance of various dealer instruments for dealer retention across brand tiers. We did however not actually measure brand-dealer fit. Clearly future research should aim to mea- sure perceived brand-dealer fit and show how this perceived fit impacts dealer perceptions and customer behavior (e.g., Aaker and Keller 1990). Our empirical findings indicate that fit is most important for economy brand customers. They request low service prices and don't want to pay for a luxurious service environment. For prestige brand customers the issue of fit may be less prevalent. The number of prestige brand customers is our sample was however limited, which makes it difficult to come up with strong significant results. Future research should aim to study larger samples of especially prestige brand customers.

\section{Management implications}

Our empirical results, albeit limited to a single country, lead to several implications for brand manufacturers and dealers. First, our finding that only dealers of volume brands contribute to brand retention suggests that manufacturers should form different expectations about the brand retention impact of investments in dealers selling and servicing different types of brands. These expectations can help manufacturers, in particular those of prestige and economy brands, to correctly assess the expected pay-offs from investments in building and maintaining close relationships with dealers to enhance consumers' brand loyalty.

Second, our result that the brand retention impact differs across brand tiers, suggests that dealers differ in their negotiating power with manufacturers. Dealers of volume brands have more negotiating power than dealers of prestige and economy brands because they add value to the manufacturer's brand. Prestige and economy brand dealers simply function as a point of purchase. This makes these dealers exchangeable for other dealers and alternative outlets (e.g., supermarkets). The success of car department stores in the UK highlights the relevance of this threat for dealers (Edmonson 2003c). Prestige and economy brand dealers should rethink their position within the channel before manufacturers use their power leverage. This is important because manufacturers might consider selling cars to consumers themselves, either through manufacturer owned outlets or through the Internet, and leaving the service function to a reduced number of (new) specialized service points.

Third, our findings that brand tier moderates the effects of dealer quality and payment equity on dealer retention suggest that dealers should pursue different strategies to ensure brand-dealer fit. This especially holds for dealers of economy brands. These dealers of should not only emphasize their low maintenance and service costs, but should create a rather sober (nonluxurious) service environment consistent with their brands price image.

\section{Limitations and future research}

Our study has several limitations that provide avenues for future research. First, our sample is restricted to one country in Europe. Future research might use cross-country com- 
parisons to study the impact of brand tier on consumers brand and dealer retention decisions and also the impact that the institutional context has on these decisions. Second, we collected data after the repurchase decision. Therefore, the responses may be biased towards the actual decision. However, as we interviewed consumers shortly after their repurchase decision, we believe that this bias should not be too problematic (cf. Punj and Brookes 2002). Third, our sample consisted of consumers regularly servicing their car at an official dealer selling that particular car brand. This may have led to an inflated importance of the dealer in the brand retention decision. Future research might address this issue by also incorporating nonofficial dealers. Fourth, we collected cross-sectional data. Future research could collect longitudinal data so that consumer heterogeneity can be explicitly modeled using latent class and/or hierarchical models. Fifth, our study does not consider asymmetric effects due to critical experiences that consumers might have had with their car, dealer, or both. Additional studies might address this issue. Sixth, decision constraints of consumers might have affected our results. For example, Lapersonne et al. (1995) have shown that 17 percent of car buyers have a consideration set size of one. More recently, Lambert-Pandraud et al. (2005) have revealed that the size of the consideration set is negatively affected by age. This would imply more loyalty among older people. Additional analysis showed that age did not affect consumer loyalty in our study. Finally, our study did not consider switching between different brand tiers. Future research could focus on this specific switching pattern. All of these directions for further research require huge data collection efforts, but will provide important new insights on the interplay between brand and dealer retention decisions.

\section{Acknowledgements}

The authors are indebted to NDA, BOVAG, ICDP and RDW for providing data and for insights into the Dutch new car market. We benefited from the research assistance of Wildrik van der Plassche, Remco Prins and Richard Paap. We appreciate the comments of participants at Marketing Science Conference 2004 and seminar participants at Tuck School of Business at Dartmouth, Frankfurt University and Free University of Amsterdam. Thanks are also due to Katrijn Gielens, Jagdip Singh, Frank Verboven, and Stefan Wuyts for helpful comments and suggestions. We also acknowledge the helpful comments of the three reviewers and the editor.

Appendix A. Classification brand tiers

\begin{tabular}{|c|c|c|c|c|c|}
\hline & Economy brand & Volume brand & Prestige brand & Total & $\#$ of interjudge agreements \\
\hline Alfa Romeo & 2 & 14 & 46 & 62 & 1,046 \\
\hline Audi & 2 & 8 & 52 & 62 & 1,337 \\
\hline BMW & 0 & 4 & 58 & 62 & 1,680 \\
\hline Chrysler & 1 & 22 & 38 & 62 & 720 \\
\hline Citroen & 7 & 48 & 7 & 62 & 1,116 \\
\hline Daewoo & 39 & 20 & 3 & 62 & 749 \\
\hline Daihatsu & 46 & 12 & 4 & 62 & 1,032 \\
\hline Fiat & 23 & 38 & 1 & 62 & 715 \\
\hline Ford & 9 & 50 & 4 & 62 & 1,205 \\
\hline Honda & 10 & 41 & 11 & 62 & 834 \\
\hline Hyundai & 40 & 20 & 2 & 62 & 763 \\
\hline $\mathrm{Kia}$ & 41 & 17 & 5 & 62 & 803 \\
\hline Lancia & 16 & 12 & 34 & 62 & 550 \\
\hline Mazda & 11 & 40 & 10 & 62 & 787 \\
\hline Mercedes & 3 & 1 & 58 & 62 & 1,644 \\
\hline Mitsubishi & 16 & 44 & 2 & 62 & 947 \\
\hline Nissan & 23 & 37 & 2 & 62 & 651 \\
\hline Opel & 10 & 40 & 11 & 62 & 787 \\
\hline Peugeot & 2 & 48 & 11 & 62 & 1,145 \\
\hline Renault & 7 & 48 & 6 & 62 & 1,145 \\
\hline Rover & 2 & 14 & 46 & 62 & 1,034 \\
\hline Seat & 31 & 26 & 5 & 62 & 465 \\
\hline Skoda & 46 & 11 & 5 & 62 & 1,032 \\
\hline Subaru & 34 & 19 & 8 & 62 & 577 \\
\hline Suzuki & 47 & 13 & 2 & 62 & 1,058 \\
\hline Toyota & 6 & 45 & 11 & 62 & 980 \\
\hline Volkswagen & 1 & 37 & 24 & 62 & 667 \\
\hline Volvo & 1 & 10 & 51 & 62 & 1,280 \\
\hline Total: & 477 & 740 & 519 & 1,736 & 26,748 \\
\hline
\end{tabular}

Note. Proportion of interjudge agreement $=26,748 /((28 \times 62 \times 61) / 2)=0.51 ;$ PRL-reliability =0.99 (Rust and Cooil 1994, p. 8). 


\section{References}

Aaker, David A. and Kevin L. Keller (1990). "Consumer Evaluations of Brand Extensions," Journal of Marketing, 54 (1), 27-42.

Ailawadi, Kusum L. (2001). "The Retail-Power Performance Conundrum: What Have We Learned?," Journal of Retailing, 77 (3), 299-318.

Anderson, James C. and James A. Narus (1995). "Capturing the Value of Supplementary Services," Harvard Business Review, 73 (1), 75-84.

Anderson, Eugene W. and Mary W. Sullivan (1993). "The Antecedents and Consequences of Customer Satisfaction for Firms," Marketing Science, 12 (2), 125-144.

Babin, Barry J., W.R. Darden and Mitch Griffin (1994). "Work and Fun-Measuring Hedonic and Utilitarian Shopping Value," Journal of Consumer Research, 20 (4), 644-656.

Bagozzi, Richard P. and Youjae Yi (1988). "On the Evaluation of Structural Equation Models," Journal of the Academy of Marketing Science, 16 (1), 74-94.

Bagwell, Laurie S. and Doughlas B. Bernheim (1996). "Veblen Effects in a Theory of Conspicuous Consumption," The American Economic Review, 86 (3), 349-374.

Baker, Julie, A. Parasuraman, Druv Grewal and Glenn B. Voss (2002). "The Influence of Multiple Store Environment Cues on Perceived Merchandise Value and Patronage Intentions," Journal of Marketing, 99 (2), 120-141.

Ben-Akiva, M. and S.R. Lerman (1985). Discrete Choice Analysis. Cambridge, MA: MIT Press.

Blattberg, Robert C. and Scott A. Neslin (1990). Sales Promotion, Concepts, Methods and Strategies. Englewood Cliffs, New Jersey: Prentice Hall.

Bolton, Ruth N. (1998). "A Dynamic Model of the Duration of the Consumer's Relationship With a Continuous Service Provider: The Role of Satisfaction," Marketing Science, 17 (1), 45-65.

Bolton, Ruth N. and Katherine N. Lemon (1999). "A Dynamic Model of Consumers Usage of Services: Usage as An Antecedent and Consequence of Satisfaction," Journal of Marketing Research, 36 (2), 171186.

Bolton, Ruth N., Katherine N. Lemon and Peter C. Verhoef (2004). "The Theoretical Underpinnings of Customer Asset Management: A Framework and Propositions for Future Research," Journal of the Academy of Marketing Science, 32 (3), 271-293.

Bucklin, Randy E. and James M. Lattin (1991). "A Two-State Model of Purchase Incidence and Brand Choice," Marketing Science, 10 (1), 24-39.

Burnham, Thomas, Judy K. Frels and Vijay J. Mahajan (2003). "Consumer Switching Costs: A Typology, Antecedents, and Consequences,' Journal of the Academy of Marketing Science, 31 (2), 109-126.

Chaudhuri, Arjun and Morris B. Holbrook (2001). "The Chain of Effects from Brand Trust and Brand Affect to Brand Performance: The Role of Brand Loyalty," Journal of Marketing, 65 (2), 81-93.

Chu, Wujin and Preyas S. Desai (1995). "Channel Coordination Mechanisms for Consumer Satisfaction," Marketing Science, 14 (4), 343-359.

Coughlan, Anne T., Erin Anderson, Louis W. Stern and Adel I. El-Ansary (2001). Marketing Channels. Upper Saddle River, New Jersey: Prentice Hall.

DeSarbo, Wayne S. and Ajay K. Manrai (1992). "A New Multidimensional Scaling Methodology for the Analysis of Asymmetric Proximity Data in Marketing Research," Marketing Science, 11 (1), 1-20.

DeWulf, Kristof, Gaby Odekerken-Schröder and Dawn Iacobucci (2001). "Investments in Consumer Relationships: A Cross-Country and CrossIndustry Exploration," Journal of Marketing, 65 (4), 33-50.

Edmonson, Gail (May 12, 2003). "VW Needs a Jump," Business Week, 14-15.

Edmonson, Gail (June 19, 2003). "BMW," Business Week, 19-24.

Edmonson, Gail (July 28, 2003). "Porsches? Aisle 7," Business Week, 22.

Fournier, Susan (1998). "Consumers and Their Brands: Developing Relationship Theory in Consumer Research," Journal of Consumer Research, 24 (4), 343-374.

Garbarino, Ellen and Mark S. Johnson (1999). "The Different Roles of Satisfaction, Trust and Commitment in Consumer Relationships," Journal of Marketing, 63 (2), 70-87.
Grewal, Dhruv, Julie Baker, Michael Levy and Glenn B. Voss (2003). "The Effects of Wait Expectations and Store Atmosphere Evaluations on Patronage Intentions in Service-Intensive Retail Stores," Journal of Retailing, 79 (4), 259-268.

Heide S Jan B. and Allen M. Weiss (1995). "Vendor Consideration and Switching Behavior for Buyers in High-Technology Markets," Journal of Marketing, 59 (3), 30-44.

Hsee, Christopher K. and France Leclerc (1998). "Will Products Look More Attractive When Presented Separately or Together?," Journal of Consumer Research, 25 (2), 175-186.

Keller, Kevin L. (2003). Strategic Brand Management, Building, Measuring and Managing Brand Equity. Upper Saddle River, NJ: Prentice Hall.

Keller, Kevin L. and David A. Aaker (1992). "The Effects of Sequential Introduction of Brand Extensions," Journal of Marketing Research, 29 (1), 35-51.

Kirmani, Amna, Sanjay Sood and Sheri Bridges (1999). "The Ownership Effect in Consumer Responses to Brand Line Stretches,' Journal of Marketing, 63 (1), 88-102.

Lambert-Pandraud, Raphaelle, Gilles Laurent and Eric Lapersonne (2005). "Repeat Purchasing of New Automobiles by Older Consumers: Empirical Evidence and Interpretations," Journal of Marketing, 69 (2), 97-113.

Lapersonne, Eric, Gilles Laurent and Jean J. Le Goff (1995). “Consideration Sets of Size One: An Empirical Investigation of Automobile Purchases,' International Journal of Research in Marketing, 12 (1), 55-66.

Lemon, Katherine N. and Stephen M. Nowlis (2002). "Developing Synergies Between Promotions and Brands in Different Price-Quality Tiers," Journal of Marketing Research, 39 (2), 171-185.

Lichtenstein, Donald R. and William O. Bearden (1989). "Contextual Influences on Perceptions of Merchant-Supplied Reference Prices," Journal of Consumer Research, 16 (1), 55-65.

Mittal, Vikas and Wagner A. Kamakura (2001). "Satisfaction, Repurchase Intent, and Repurchase Behavior: Investigating the Moderating Effect of Consumer Characteristics," Journal of Marketing Research, 38 (1), 131-142.

Mittal, Vikas, Pankaj Kumar and Michael Tsiros (1999). "Attribute-Level Performance, Satisfaction and Behavioral Intentions over Time: A Consumption System Approach,” Journal of Marketing, 63 (2), 88-101.

Miyazaki, Anthony D., Dhruv Grewal and Ronald C. Goodstein (2005). "The Effect of Multiple Extrinsic Cues on Quality Perceptions: A Matter of Consistency," Journal of Consumer Research, 32 (1), 146-153.

Nunnally, J.C. (1978). Psychometric Theory second ed. New York: MacMillan.

Oliver, Richard L. and John E. Swan (1989). "Equity and Disconfirmation Perceptions as Influences on Merchant and Product Satisfaction," Journal of Consumer Research, 16 (3), 372-383.

Parasuraman, A., Valarie A. Zeithaml and Leonard L. Berry (1985). "A Conceptual Model of Service Quality and its Implications for Future Research," Journal of Marketing, 49 (4), 41-51.

Park, C. Whan, Sandra Milberg and Robert Lawson (1991). "Evaluation of Brand Extensions: The Role of Product Feature," Journal of Consumer Research, 18 (2), 185-194.

Punj, Ginish and Richard Brookes (2002). "The Influence of Pre-Decisional Constraints on Information Search and Consideration Set Formation in New Automobile Purchases," International Journal of Research in Marketing, 19 (4), 383-400.

Russell, Gary J. and Ruth N. Bolton (1988). "Implications of Market Structure for Elasticity Structure,” Journal of Marketing Research, 25 (3), 229-241.

Rust, Roland T. and Bruce Cooil (1994). "Reliability Measures for Qualitative Data: Theory and Implications," Journal of Marketing Research, 31 (1), 1-14.

Rust, Roland T., Katherine N. Lemon and Valarie A. Zeithaml (2004). "Return on Marketing: Using Customer Equity to Focus Marketing Strategy," Journal of Marketing, 68 (1), 109-127.

Seiders, Kathleen L., Glenn B. Voss, Dhruv Grewal and Andrea L. Godfrey (2005). "Do Satisfied Customers Buy More? Examining Moderating Influences in a Retailing Context," Journal of Marketing, 69 (4), 26-43. 
Sirohi, Niren, Edward W. McLaughlin and Dick R. Wittink (1999). "A Model of Consumer Perceptions and Store Loyalty Intentions for a Supermarket Retailer," Journal of Retailing, 74 (2), 223-246.

Sloot, Laurens M., Peter C. Verhoef and Philip H. Franses (2005). "The Impact of Brand Equity and the Hedonic Level of Product to Consumer Out of Stock Reaction," Journal of Retailing, 81 (1), 15-34.

Steiner, Robert L. (2004). "The Nature and Benefits of National Brand/Private Label Competition," Review of Industrial Organization, 24 (2), 105-127.

Sullivan, Mary W. (1998). "How Brand Names Affect the Demand of Twin Automobiles," Journal of Marketing Research, 35 (2), 154-165.

Verhoef, Peter C. (2003). "Understanding the Effect of Customer Relationship Management Efforts on Customer Retention and Customer Share Development," Journal of Marketing, 67 (4), 30-45.

Weiss, Allen M. and Erin Anderson (1992). "Converting from Independent to Employee Sales Forces: The Role of Perceived Switching Costs," Journal of Marketing Research, 29 (1), 101-116.
Yin, Xiaoli and Edward J.Zajac (2004). "The Strategy/Governance Structure Fit Relationship: Theory and Evidence in Franchising Arrangements," Strategic Management Journal, 25 (4), 365-383.

Yin, Lam, Shun Venkatesh Shankar, M. Krishna Erramilli and Bvsan Mruth (2004). "Customer value, satisfaction, loyalty and switching costs: An Illustration from a Business-to-Business Service Context," Journal of the Academy of Marketing Science, 32 (3), 293-312.

Zajac, Edward J., Matthew S. Kraatz and Rudi K. Bresser (2000). "Modeling the Dynamics of Strategic Fit: A Normative Approach to Strategic Change," Strategic Management Journal, 21 (4), 429453.

Zeithaml, Valarie A. (1988). "Consumer Perceptions of Price, Quality, and Value: A Means-End Model and Synthesis of Evidence," Journal of Marketing, 52 (3), 2-23.

Zeithaml, Valarie A., Leonard L. Berry and A. Parasuraman (1996). "The Behavioral Consequences of Service Quality," Journal of Marketing, 60 (2), 31-46. 